\title{
The Gallery Walk Teaching and Learning and Its Potential Impact on Students' Interest and Performance
}

\author{
Mazdalifa Makmun ${ }^{\mathrm{a}}$, Khoo Yin Yin $^{\mathrm{b}}$ and Zainizam Zakariya ${ }^{\mathrm{c}}$ \\ ${ }^{a, b, c}$ Department of Economics, Faculty of Management and Economics, \\ Sultan Idris Education University, Perak, Malaysia \\ Corresponding author: iffamakmun93@gmail.com
}

To cite this article (APA): Makmun, M., Yin, K. Y., \& Zakariya, Z. (2020). The Gallery Walk Teaching and Learning and Its Potential Impact on Students' Interest and Performance. International Business Education Journal, 13(1), 17-22. https://doi.org/10.37134/ibej.vol13.1.2.2020

To link to this article: https://doi.org/10.37134/ibej.vol13.1.2.2020

\begin{abstract}
Gallery Walk has the potential to improve the effectiveness of teaching and learning. Many teachers have especially been interested in using this strategy as a means of providing learning opportunities. This paper explores and discusses the definition of gallery walk, and the potential of this approach and its limitations. This article discusses the advantages of gallery walk and shows that researchers are still wondering on how gallery walk will help reaching the goals of a better learning, and how it will be different from the rest of learning method. This study can become a guidance or reference for educators, and researchers in the field.
\end{abstract}

\section{Keywords:}

Gallery walk, potential, effect, students' interest, students' performance

\section{INTRODUCTION}

According to the Secondary School Curriculum (KSSM), the Elective Curriculum (MPEI) has been formulated by the Ministry of Education for students (Ministry of Education Malaysia, 2015). The MPEI curriculum is one of the initiatives to develop physically and spiritually balanced human capital, good morality, creative and innovative as well as adopting a culture of professionalism to address $21^{\text {st }}$ century challenges in line with the national education goals (Ministry of Education Malaysia, 2018). The gallery walk is a strategy that enables students to move from their chair, think together, and discuss with others students (Rodenbaugh, 2015). According to previous researchers, traditional teaching and learning methods today are no longer able to realize the aims and goals of 21 centuries-old education (Kumar, Wotto \& Belanger, 2018; Brantes, Zanela, Freitas, \& Schlemmer, 2013; Barati \& Zolhavarieh, 2012). Therefore, gallery walk can be used to replace traditional methods of learning. This is because according to Kennedy, Mimmack and Flannery (2012), this learning method can greatly benefit the learning process. The used of the gallery walk can stimulate communication among students, critical thinking, and enable students to use critical evaluation of new information (Kennedy et al., 2012). According to Kruea-In and Thongperm (2014), gallery walk can enhance the classroom management, student engagement, student 
responsibility and discussion in groups. By using the gallery walk, students can improve their understanding of the topics being learned, in more enjoyable learning environment and the team's interpersonal skills will be enhanced (Kennedy et al., 2012; Kruea-In \& Thongperm, 2014; Rodenbaugh, 2015).

\section{DEFINITION}

According to Rodenbaugh (2015) and Mark (2006), gallery walk is a strategy that enabled students to get up from their chair, think with peers and discuss with other team members. This is because the gallery walk requires each student team to go around each station to answer other teams' questions at each station (Rodenbaugh, 2015; Mark, 2006). Furthermore, once all team members have visited every station, presentations and discussions will take place (Rodenbaugh, 2015; Mark, 2006). Gallery walk is an excellent way to identify whether students understand the content of lessons they are learning. Stewart and Beaudry (2017) also agreed with the above statement.

According to Stewart and Beaudry (2017), gallery walk is a discussion method that enabled students to get up from their chairs and ask them to become active participants during a discussion process. In their research, they added a new strategy of incorporating mobile technology into the gallery walk activity (Stewart \& Beaudry, 2017). According to Allen and Tanner (2005), the gallery walk technique is one of the active learning methods where students discover new information, organize it in meaningful ways, and have the opportunity to describe it to peers. This method emphasizes interaction and communication between peers and encourages students to learn independently rather than relying on teachers to teach. At the end of the investigation, students will be required to demonstrate a presentation to explain the topic of learning in more detail (Allen and Tanner, 2005).

\section{HOW TO USE GALLERY WALK METHOD}

As stated by Franzblau and Haque (2018), the gallery walk allowed students to talk about empirical strategies for responding to common learning subjects. Firstly, the facilitator separates the students into several small group discussions depending on the number of subject explained in the classroom discussion. After that, each group member discusses the subject given. The group discussion is written on the flipchart and then posted on the classroom wall. Then, the facilitator asks all group members to stand in front of their poster paper. Next, the facilitator instructs all group members to visit all station. The visit will come to an end when all group members return to their station.

\section{POTENTIAL IMPACTS OF GALLERY WALK}

According to Rodenbaugh (2015), the study found that the gallery walk has many advantages in the process of teaching and learning. The gallery walk can encourage critical thinking of students, communication between peers and students can practice critical evaluation to additional information (Rodenbaugh, 2015). De Pedro, Jackson, Campbell, Gilley and 
Clarelli (2016) further added that gallery walk encouraged students to give specific examples or to relate what they see or experience with what they are learning inside the classroom. The gallery walk also created new information for application in the daily life of students (De Pedro et al., 2016).

According to Kennedy, Mimmack and Flannery (2012), teachers and students collect posters on the topic of learning and all the posters were transferred to an online gallery. This created a chance for students to study more about the topic with their peers in more interesting, interactive and fun ways. As the use of online gallery walk is rarely used in the $12^{\text {th }}$ grade, this online gallery walk is considered as an innovative learning method for active student learning (Kennedy et al., 2012).

\section{The impacts of gallery walk on students' interests}

In this section, the researchers identify the impact of using the gallery walk on students' interest from previous studies. According to Rodenbaugh (2015), the gallery walk could stimulate physical activity and create enjoyment in the classroom. According to Hendri and Retika (2017), the gallery walk encouraged students to communicate and share ideas with their peers and not passively listening to the instructor, and stimulated and enhanced the students' various cognitive skills that involve analysis, assessment and synthesis. The gallery walk also provided opportunities for students to move around their classroom, attracted their attention and stimulated their interest in learning more about a topic (Hendri \& Retika, 2017; Rodenbaugh, 2015).

According to Francek (2006), a study was conducted to measure teaching response using gallery walk as a learning strategy. The findings show that teachers perceived gallery walk activity positively in terms of flow, organization, effectiveness and learning experience while also stimulating student participation in communication and exchange of ideas (Francek, 2006). Learning is considered more interesting and less stressful than indirectly stimulating students' interest in participating in the group activities. Kahayun et al. (2015) proposed to study the impact of using gallery walk towards History subject. The results showed that students are more interested in learning the subject after using this learning method (Francek, 2006; Kahayun et al., 2015).

Yani, Abdi and Harun (2017) also said that the cooperative learning method embedded in the gallery walk stimulated and strengthened pupils' memory because of the things students learn and observe directly. Furthermore, the gallery walk also enhanced student activities and attracted students to learn while prevented students from getting bored (Yani et al., 2017). Overall, 94 per cent of students said that learning using the gallery walk cooperative learning method was very interesting and engaging, apart from helping students to understand their learning problems (Yani et al., 2017).

\section{The impacts of gallery walk methods on students' performance}


In this section researchers identify the impact of using the gallery walk on student performance based on previous studies. According to Mariyaningsih (2014), teachers should be creative in selecting the appropriate method and the findings of that study showed that the execution of the gallery walk to teach Account subjects was effective and the students' performance in the subject of Accounting increased after using this method. In support, Fannia, Rini and Arman (2017) found that the gallery walk improved students' performance. The results showed that in the pre-test, 21 students scored more than 75 percent while 36 students scored more than 75 percent on the post-test (Fannia et al., 2017). This indicated that the gallery walk increased the number of students who scored more than 75 percent in a test.

Similarly, Franzblau and Haque (2018) stated that this learning strategy enhanced students' achievement in learning. According to Farrah (2015), students' communication ability increased after participating in the gallery walk. It could be seen from the results of the study that there was an improvement in the average scores of students in the first and second tests. This indirectly indicated that by using the gallery walk, students' performance were improved (Franzblau \& Haque, 2018; Farrah, 2015).

The findings of Hogan and Cernusca (2011) also showed that student-centred learning was better after using the gallery walk and there was a correlation between communication skills and independent learning in two classes after using the gallery walk. According to Hendri and Retika (2017), the finding suggested that there is a significant difference between pre-test and post-test scores for students who participated in the gallery walk. Thus, there is a significant difference in student' performance following the gallery walk (Hendri \& Retika, 2017; Hogan \& Cernusca, 2011).

\section{RECOMMENDATIONS ON STRATEGIES AND METHODS OF IMPLEMENTATION}

Gallery walk is a promising strategy for teaching process because this learning method encourages active participation of students, collaboration within group and peers and the use of this method also encourages students' critical thinking since students are more likely to exchange views among a team of peers. Teachers also should be periodically trained to adopt innovative and creative teaching strategies such as the use of mobile learning method in gallery walk to further enhanced the benefits for students. Head teachers, principals, school administrators are also encouraged to support teachers to use gallery walk in class since it involves experimentation and demonstration that can increase students' achievement.

\section{CONCLUSION}

The traditional learning methods are no longer the best option to enhance student's performance. This paper has highlighted some of the detaile issues that students, teachers and coordinators might have before considering on using a gallery walk for learning process. It was emphasized that gallery walk has many advantages in the learning process. Teachers use 
the gallery walk as a strategy to enable students to discuss their work with their friends and to study the learning materials in the classroom. The use of gallery walk was reported by many prior researchers to enhance active participation of students in a lesson, collaboration among students, and critical thinking skills. Overall, it implies that the used of gallery walk as a teaching and learning methods helps students improve on their academic performance.

\section{REFERENCES}

Allen, D., \& Tanner, K. (2005). Infusing active learning into the large-enrolment biology class: Seven strategies, from the simple to complex. Cell Biology Education, 4, 262-268.

Barati, M. \& Zolhavarieh, S. (2012). Mobile learning and multi mobile service in higher education. International Journal of Information and Education Technology, 2(4), 297-298.

Brantes, F., J., Zanela, K. A., Freitas, A., \& Schlemmer, E. (2013). Mobile learning: Definition, uses and challenges. Increasing Student Engagement and Retention Using Mobile Applications: Smartphones, Skype and Texting Technologies, 6, 47-82.

De Pedro, K. T., Jackson, C., Campbell, E., Gilley, J. \& Clarelli, B. (2016). Creating trans- inclusive schools: Introductory activities that enhance the critical consciousness of future educators. International Journal of Teaching and Learning in Higher Education, 28(2), 293-301.

Fannia L., Rini \& Arman E.Y. (2017). Application of gallery walk learning methods to enhance learners' learning on the subject of atomic structure and periodic system of new element $\mathrm{X}$ class Mia Sman2 Pekan baru. Journal of Faculty of Science and Education, 4(1), 1-13.

Farrah, Z. (2015). Enhancing Students' Speaking Skill through Gallery Walk Technique. Indonesia Language and Language Teaching Journal, 8(2), 253-268.

Francek M. (2006). Promoting discussion in the science classroom using gallery walks. J Coll Sci Teach, 36(1), 27-32.

Franzblau, L., \& Haque, F. (2018). Using gallery walks to navigate hospital hierarchy. Medical Education, 52(11), 1185-1186.

Hendri \& Retika. (2017). The use of gallery walk to enhance the speaking achievement of the ninth grade students of Smp Pgri 1 Palembang. Journal of Language and Literature, 6(1), 50-56.

Hogan, J. P. \& Cernusca, D. (2011). Integrating gallery walks and wikis in a synergic instructional activity: An exploratory study of students' perceptions. Computers in Education Journal, 21(4), $37-48$.

Kahayun, Wakidi \& Yustina (2015). The influence of the gallery walk on the interest of studying history in Sman 1 Natar. Journal of Education and Historical Research, 3(2), 1-14.

Kennedy, M. J., Mimmack, J., \& Flannery, K. B. (2012). Innovation in data-driven decision making within SWPBIS systems: Welcome to the gallery walk. Beyond Behaviour, 21(3), 8-14.

Kruea-In, N., \& Thongperm, O. (2014). Teaching of science process skills in Thai contexts: Status, supports and obstacles. Social and Behavioural Sciences, 141, 1324-1329.

Kumar Basak, S., Wotto, M. \& Belanger, P. (2018). E-learning, M-learning and D-learning: Conceptual definition and comparative analysis. E-Learning and Digital Media, 15(4), 191216.

Mariyaningsih N. (2014). Improvement of financial reporting activity and results of financial accounting learning materials through the standard walk-in gallery method. Journal of Educational Economics in Educational Dynamics, 14(1), 57-59.

Mark, F. (2006). Promoting discussion in the science classroom using gallery walks. Journal of College Science Teaching; Washington, 36(1), 27-31. 
Ministry of Education Malaysia. (2016). Summary Circular Letter Number 9. Secondary Curriculum Implementation Gradually Beginning 2017. 2017. Ministry of Education Malaysia Post Release Number 19 Year 2016. Putrajaya, Malaysia

Ministry of Education Malaysia. (2018). Announcement of the Malaysian Examination Certificate (SPM) Decision in 2017. Putrajaya, Malaysia

Rodenbaugh, D. W. (2015). Maximize a team-based learning gallery walk experience: Herding cats is easier than you think. Advances in Physiology Education, 39(4), 411-413.

Stewart, M. A. \& Beaudry, J. (2017). The gallery walk: Educators step up to build assessment literacy. Journal of Learning Professional, 38(6), 48-53.

Yani, Abdi \& Harun. (2017). Implementation of a cooperative learning model of the gallery walk to enhance the geography learning outcomes of state $\mathrm{x}-\mathrm{b}$ students in the 7 th grade. Journal of Geography Education Unsyiah, 2(2), 59-69. 